\title{
ECONOMIC DEVELOPMENT AT THE COST OF INDIGENOUS LAND
}

\author{
Brian Chama \\ European School of Economics
}

\section{INTRODUCTION}

The International Labour Organisation (ILO) convention number 169 is primarily concerned with the indigenous groups and land rights. ${ }^{1}$ The recognition of indigenous groups as having a right to natural resources is inextricably tied to the right to land. The convention gives indigenous groups the right to natural resources on land and to participate in the use, management and conservation of these resources. ${ }^{2}$ This right has been acknowledged as essential to the survival of indigenous groups. ${ }^{3}$ The right to self-determination postulates the right of and indigenous group to determine its own destiny and is therefore at the core of the democratic entitlements.

The countries that have ratified the convention are obliged to develop laws and procedures so as to be able to implement the obligations. This may be by way of constitutional provisions and specific implementing legislations. This can also be in terms of procedures like those pertaining to granting of environmental and exploration licenses to companies. This convention is aimed directly at governments and is binding only to countries that have ratified it and not at the private sector even though may be relevant to the private sector indirectly. ${ }^{4}$ There may be instances when companies may be held directly responsible for its implementation.

The ILO convention number 169 is a key instrument in the body of international law that relates to indigenous groups. It was adopted in

1 Lidija, K. (2009) The Right to Adequate Food and Indigenous People. Available from: http://www.fao.org/righttofood/publi09/ind_people.pdf [Accessed 21/06/2010]

2 Raja, D., and Henriksen, J. (2010) Inclusion of indigenous peoples' rights in the new constitution of Nepal. Available from:

http://www.ilo.org/wcmsp5/groups/public/_-ed_norm/--normes/documents/publication/ wcms_123847.pdf [Accessed 21/06/2010]

3 Dorough, S. (1995) State of the world's indigenous peoples. Available from: http://www.un.org/esa/socdev/unpfii/documents/SOWIP_chapter6.pdf ) [Accessed 21/06/ 2010]

4 ILO (2007) Convention 169 and the Private Sector. Available from: http://www.ifc.org/ifcext/enviro.nsf/AttachmentsByTitle/p_ILO169/\$FILE/ILO_169.pdf [Accessed 21/06/2010] 
1989 and has been ratified only by 22 countries as of April 2010.5 The convention is limited because of few countries that have ratified it. This has made it difficult as a reference point by indigenous groups making claims to the land. ${ }^{6}$ Therefore, appealing to other human rights principles have proved effective when making land claims.

There has been a lot of public awareness on the plight of indigenous groups in recent years. The land which indigenous groups occupy has been identified as critical to their survival. The problem has been on establishing ownership to the land they do not hold title. ${ }^{7}$ The issue of holding land title by indigenous groups has made it difficult to prove land ownership. ${ }^{8}$ There have been few positive developments in favour of indigenous groups. The African Commission on Human and People's Rights for example condemned the expulsion of Endorois indigenous group from their land in Kenya. This has been perceived as a major victory for indigenous groups across Africa. ${ }^{9}$

The overarching question is where the responsibility to guarantee land claims should lie in a world of transnational companies and economic development. Is a customary law and international law vital source for indigenous land claims? Can indigenous groups acquire land without the support of local legal provisions? What is the impact of transnational companies on indigenous land claims?

\section{The Indigenous Groups}

There are about 250 million indigenous people who are found in at least seventy-four countries worldwide and accounting for six percent of the world population. ${ }^{10}$ Some scholars put the figures of indigenous people worldwide between 250 to 300 million. ${ }^{11}$ The indigenous people are best defined as groups traditionally regarded and self-defined as descend-

5 ILO (2010) Convention No C169. Available from:

http://www.ilo.org/ilolex/cgi-lex/ratifce.pl?C169 [Accessed 22/06/2010]

6 ILO (2007) Convention 169 and the Private Sector. Available from:

http://www.ifc.org/ifcext/enviro.nsf/AttachmentsByTitle/p_ILO169/\$FILE/ILO_169.pdf [Accessed 21/06/2010]

7 Wachira, M. (2008) Vindicating indigenous peoples' land rights in Kenya. Available from:

http://upetd.up.ac.za/thesis/available/etd-01212009-162305/unrestricted/01 chapters 1-2.pdf [Accessed 21/11/2009]

8 Kiraz, J. (2009) Venezuela Grants Land to Indigenous Communities on Indigenous Resistance Day. Available from:

http://venezuelanalysis.com/news/4858 [Accessed 02/06/2010]

9 Human Rights Watch (2010) Kenya: Landmark Ruling on Indigenous Land Rights. Available from: http://www.hrw.org/en/news/2010/02/04/kenya-landmark-ruling-indigenousland-rights [Accessed 17/11/2010]

10 Saugestad, S. (2009). Indigenous People of the World. Tromso: University of Tromso

11 Huckaby, W. (2009) Indigenous Peoples in the 21st Century. Available from: http:// www.america.gov/media/pdf/ejs/0609.pdf [Accessed 21/06/2010] 
ants of the original inhabitants of lands with which they share a strong and very often spiritual bond.

The indigenous groups are regarded as indigenous on account of their descent from the populations which inhabited the geographical region at the time of conquest or colonisation or the establishment of present state boundaries. They irrespective of their legal status retain some or all of their own social, economic, cultural and political institutions. ${ }^{12}$

\section{LAND Ownership STRUgGles}

The major critical commonality faced by indigenous groups is the eviction from their land and being denied access to the natural resources upon which their survival depends. ${ }^{13}$ The eviction from land is very often caused by establishment of national parks, large-scale commercial enterprises such as mining, logging, commercial plantations, oil exploration and dam construction. ${ }^{14}$ The dismissal from land has undermined the knowledge systems through which indigenous groups have sustained their lives over the centuries. The land of indigenous groups is gradually shrinking and this makes them vulnerable and unable to cope with environmental uncertainty threatening their future existence.

The indigenous groups worldwide continue to face serious difficulties in holding on to their land. Their existence and survival is always threatened with continuous assimilation policies, marginalization, forced removal or relocation, denial of land rights, impacts of large-scale development, and abuses by military forces and a host of other abuses which are a reality in indigenous communities around the world. ${ }^{15}$ There are many examples of violence on indigenous groups reported worldwide and mainly perpetrated against those defending their lands. There are a myriad of testimonies of forced relocation of indigenous groups and dispossession of their lands at the expense of economic development by transnational companies.

The Bushmen living in their traditional hunting grounds in the Central Kalahari of Botswana have been struggling with forced relocation from their homelands, without any substantive address of their right to

12 Lindsey, W. (2001) Indigenous Lands as Cultural Property: A New Approach to Indigenous Land Claims. Available from: http://www.law.duke.edu/shell/cite.pl?54+Duke+L.+J. +1061 [Accessed 21/06/2010]

13 Survival International (2009) Botswana official admits: Bushmen were evicted for diamonds. Available from: http://www.survivalinternational.org/news/4878 [Accessed 21/06/ 2010]

14 Monrás, J. (2006) Indigenous peoples in Africa: The forgotten peoples?Available from: http://www.achpr.org/english/Special\%20Mechanisms/Indegenous/ACHPR\%20 WGIP\%20Report\%20Summary\%20version\%20ENG.pdf Accessed 21/06/2010]

15 Dorough, S. (1995) State of the world's indigenous peoples. Available from: http://www.un.org/esa/socdev/unpfii/documents/SOWIP_chapter6.pdf ) [Accessed 21/06/ 2010] 
ancestral land. ${ }^{16}$ The land has been taken by the Botswana government to pave way for mining and tourism investments. This is despite the Bushmen winning the court case granting them the right to their land. The government has refused to provide water to the Bushmen communities arguing that the land in question is meant for animal inhabitation. The Bushmen have frequently faced detention due to the criminalization of hunting social activities for their livelihood and survival. There have been more than 50 Bushmen who have been arrested in recent years and detained by the Botswana government for hunting to feed their families. ${ }^{17}$

In Brazil, there has been a conflict between indigenous groups, gold miners and cattle ranchers concerning land ownership with little international notice or attention. ${ }^{18}$ This is despite the adoption of the legislation by the government of Brazil to demarcate the lands. The reality on the ground has been dramatically violent towards the indigenous groups. There has been urgent appeals from the Guarani-Kaiowa in the state of Mato Grosso do Sul concerning eviction notices received despite the fact that their lands were demarcated as indigenous lands in $2004 .{ }^{19}$ In 2007 , a gunman shot dead a 70 year old Guarani woman while resisting relocation from her indigenous land. ${ }^{20}$ What has even made the situation worse for the indigenous groups is the granting of environmental license for the construction of the controversial Belo Monte hydro-electric dam in the Amazon by the Brazilian government. ${ }^{21}$ This will affect the livelihoods of thousands of indigenous groups who depend on the forest and the river for food and water and some faces removal from their ancestral land.

The Gibe III dam construction in the lower Omo river basin in Ethiopia is meant to generate electricity and bring about economic development in the region. ${ }^{22}$ The hydroelectric dam project will devastate the

16 Id.

17 Survival International (2010) There are 100,000 Bushmen in Botswana, Namibia, South Africa and Angola. Available from:

http://www.survivalinternational.org/tribes/bushmen [Accessed 28/06/2010]

18 Dorough, S. (1995) State of the world's indigenous peoples. Available from:

http://www.un.org/esa/socdev/unpfii/documents/SOWIP_chapter6.pdf ) [Accessed 21/06/ 2010]

19 Id.

20 Survival International (2007) Guarani Indian woman killed by gunman. Available from:

http://www.survivalinternational.org/news/2157 [Accessed 28/06/2010]

21 Survival International (2010) Brazil grants license for controversial Amazon megadam. Available from:

http://www.survivalinternational.org/news/5510 [Accessed 11/11/2010]

22 Africa Resources Working Group (2009) A Commentary on the Environmental, Socioeconomic and Human Rights Impacts of the Proposed Gibe III Dam in the Lower Omo River Basin of Ethiopia. Available from: http://www.arwg-gibe.org/uploads/ARWG_COMMEN TARY.GIBE_III_DAM.downstreamEIA.pdf [Accessed 28/06/2010] 
land of many indigenous groups. The dam will end the Omo's natural flood, which deposits fertile silt on the river banks, where the indigenous groups cultivate the crops when the waters recede. In a region where drought is commonplace, this will have devastating consequences for the indigenous source of livelihood and food supplies. The Ethiopian government plans to lease huge tracts of indigenous land in the Omo Valley to foreign companies and governments for large-scale production of crops, including bio-fuels, which will be fed by water from the dam. The Ethiopian government is clamping down on indigenous organizations making it impossible for communities to hold meetings about the dam. ${ }^{23}$

The leaders of the Ardoch Algonquin in Canada have had legal action taken against them for their efforts to block uranium exploration and mining on lands that have been claimed by the Algonquins. ${ }^{24}$ The lack of procedures to affirm indigenous land rights is exacerbated by the imposition of major developments that favour multinational corporations, and "criminalize" indigenous groups' protests. The rampant actions of large economic and corporate forces often appear to go unrestrained by governments, who are ultimately responsible for the prevention of violations and abuses of indigenous human rights by third parties. ${ }^{25}$

There are reports from different countries of arbitrary arrests of indigenous groups as well as other forms of threats and intimidations. ${ }^{26}$ The forced removals and disappearances of indigenous persons are taking place in many parts of the world. The cases mentioned in this article are not an exhaustive list as such cases are only the known violations based upon communications which has come to the public domain. ${ }^{27}$

There are currently many development projects being imposed upon indigenous communities include mining, resort developments, highway construction, establishment of national parks as well as oil and gas exploration and exploitation. ${ }^{28}$ It should be noted that even though the indigenous groups have continued to suffer land loses since the period of colonial invasion. The situation has become even worse with the coming

23 Survival International (2010) Giant dam to devastate 200,000 tribal people in Ethiopia. Available from: http://www.survivalinternational.org/news/5683 [Accessed 21/06/2010]

24 CBC News (2007) Ontario Algonquins suspend uranium site occupation. Available from: http://www.cbc.ca/canada/ottawa/story/2007/10/19/ot-sharbot-lake-071019.html [Accessed 17/11/2010]

25 Dorough, S. (1995) State of the world's indigenous peoples. Available from: http://www.un.org/esa/socdev/unpfii/documents/SOWIP_chapter6.pdf ) [Accessed 21/06/ 2010]

26 Survival International (2010) New wave of violence in West Papua. Available from: http://www.survivalinternational.org/news/6120 [Accessed 28/06/2010]

27 Dorough, S. (1995) State of the world's indigenous peoples. Available from: http://www.un.org/esa/socdev/unpfii/documents/SOWIP_chapter6.pdf ) [Accessed 21/06/ 2010]

28 Survival International (2010) Safari lodge under attack for failing Bushmen. Available from: http://www.scoop.co.nz/stories/WO1004/S00073.htm [Accessed 22/06/2010] 
of the transnational companies whose businesses have been multinational in character. The so called large scale development projects in different countries being spearheaded by transnational companies has led to massive and forcible evictions and removal from homes and lands of indigenous groups. This has been mainly due to many governments preferring adverse developments spearheaded by multinational companies on indigenous lands than giving indigenous groups a platform to hear their voices regarding their land.

There are scholars who have argued that it is only by appealing to international law and customary law as points of references that land can be claimed effectively by indigenous groups worldwide.

\section{INTERNATIONAL LAW}

Historic injustice is an important justification for international law concerning indigenous groups and dispossession of their lands. ${ }^{29}$ The world's indigenous groups are bound by the common experience of being "discovered" and subjected to colonial explorations styles of their territories leading to loss of millions of hectares of land. ${ }^{30}$

The international law protects the land of indigenous groups in several ways including human rights provisions. ${ }^{31}$ The indigenous groups have a right to their land under contemporary international law. The ILO convention number 169 affirms collective land rights to which the indigenous groups are entitled. ${ }^{32}$ The concept of indigenous territories is deemed to cover the total environment of the area which the groups occupy.

The ILO convention number 169 is a legally binding international treaty that deals specifically with indigenous groups and the right to their ancestral land. It includes a recourse mechanism which has a committee of experts on the application of conventions and review of recommendations. ${ }^{33}$ If the committee is actively used, it is an effective method for overseeing government behaviour and actions toward indigenous groups in countries that have ratified the convention. The convention cannot be underestimated because of the efforts of trade unions and human rights

29 Huckaby, W. (2009) Indigenous Peoples in the 21st Century. Available from: http:// www.america.gov/media/pdf/ejs/0609.pdf [Accessed 21/06/2010]

30 Id.

31 ILO (2010) Convention No C169. Available from: http://www.ilo.org/ilolex/cgi-lex/ratifce.pl?C169 [Accessed 22/06/2010]

32 Raja, D., and Henriksen, J. (2010) Inclusion of indigenous peoples' rights in the new constitution of Nepal. Available from:

http://www.ilo.org/wcmsp5/groups/public/—-ed_norm/—-normes/documents/publication/ wcms_123847.pdf [Accessed 21/06/2010]

33 Dorough, S. (1995) State of the world's indigenous peoples. Available from: http://www.un.org/esa/socdev/unpfii/documents/SOWIP_chapter6.pdf ) [Accessed 21/06/ 2010] 
support groups such as Survival International and Amnesty International who have helped to serve the lives of many indigenous groups worldwide.

The international laws consist of rules governing the relations among states and the recent scope has included individuals and international organisations. The international laws have provided provisions that protect indigenous land in a variety of ways and those focusing on human rights claims have proven the most effective, finding acceptance in both domestic and international courts.

The international human rights laws have been used in land claims by the indigenous groups and have proved vital in securing their traditional lands. ${ }^{34}$ Some of the indigenous groups in many parts of the world have argued that the right to cultural system cannot be enjoyed without securing their traditional land as it is inseparable to cultural identity and preservation. ${ }^{35}$ The convention signatories have been urged to respect the special relations that indigenous groups have with their lands and to establish procedures to resolve conflicts.

\section{Customary Law}

The customary law has been a significant element both in legal and in cultural terms when it comes to establishing legitimacy over land by indigenous groups. The customs are the very foundation of law, and all peoples do have customs which to a larger or lesser degree regulate social life and practices. ${ }^{36}$

The major problem which has been encountered when appealing to customary law is that the main customary law is orally sustained and transmitted. This has led to difficulties in gaining acceptance in legal contests in court. One should remember that customary law is a legal concept, and as such it is part of state law and readily recognized when it comes from the majority population. The problem arises when indigenous groups advancing their claims to land and title point to their customary laws. The power of evidence of such customary laws is not infrequently denied by the courts for the mere reason that they are not written. The Canadian Aborigines the Gitksan and Wet'suwet'en used oral histories and traditions as evidence in court to prove legal land own-

34 Lindsey, W. (2001) Indigenous Lands as Cultural Property: A New Approach to Indigenous Land Claims. Available from: http://www.law.duke.edu/shell/cite.pl?54+Duke+L.+J. +1061 [Accessed 21/06/2010]

35 Lindsey, W. (2001) Indigenous Lands as Cultural Property: A New Approach to Indigenous Land Claims. Available from: http://www.law.duke.edu/shell/cite.pl?54+Duke+L.+J. +1061 [Accessed 21/06/2010]

36 Svensson, T. (2002) Indigenous rights and customary law discourse comparing the nisga' $a$ and the sámi. Available from: http://www.jlp.bham.ac.uk/volumes/47/Svensson-art.pdf [Accessed 22/06/2010] 
ership. ${ }^{37}$ The oral traditions and histories were placed on an equal footing with the types of historical evidence that courts are familiar with for the determination of historical truth. Even though oral history has little value as legal proof, it is significant in maintaining cultural distinctiveness and in making a nation regardless of how small in number. ${ }^{38}$ The Meriam people of Murray Island in the Torres Strait in Australia were acknowledged by the court as having had a pre-existing customary system of law which was traditionally connected to land ownership. ${ }^{39}$ They were accepted as initial occupiers of the land and legally entitled as initial owners. ${ }^{40}$

The oral tradition is highly informative in giving substance to land claims because it offers cultural legitimacy to the land claims in question. According to Julie Cruikshank, a leading anthropologist in this particular field of inquiry, "oral tradition or history in reference to land claims does three things: it expresses, confirms, and asserts ownership to land". ${ }^{41}$ The Ayuukhl Nisga'a, an indigenous group argue that oral tradition and history conveys rules that governed and will continue to govern how land is allocated and used. It reflects a characteristic social organization that points to and reaffirms cultural autonomy.

The major problem under customary law is on which approach to take in registering land title to indigenous groups. The customary laws in many regions of the world of ten follow the Western concept of registering land titles to individuals than groups while many indigenous groups worldwide have been claiming for communal land title registration:

In 2001, Cambodia included a chapter in the land law registration to include communal lands registration by indigenous communities, providing a mechanism to safeguard indigenous groups land in the form of communal land titles. However, no such titles have yet been granted. ${ }^{42}$

In 2005, the communal customary land tenure was under assault in both Australia and Papua New Guinea. It was claimed that communal

37 Borrows, J. (1999) Sovereignty's Alchemy: An analysis of Delgamuukw v. British Columbia. Available from: http://www.ohlj.ca/archive/articles/37_3_borrows.pdf [Accessed 06/ 07/2010]

38 Id.

39 French, R. (2008) Judicial Conference of Australia National Colloquium Rolling a Rock Uphill? Available from: http://www.hcourt.gov.au/speeches/frenchcj/frenchcj100ct08. pdf [Accessed 01/07/2010]

40 Graeme, N. (2002) Native Title Ten Years On: Getting on with the job or sitting on the fence? Available from: http://www.nntt.gov.au/News-and-Communications/Speeches-and-papers/Documents/2002/Speeches\%20NT\%20ten\%20years\%20on\%20Neate\%20May\%202002. pdf [Accessed 01/07/2010]

41 Id.

42 Permanent Forum on Indigenous Issues (2007) Available from: http://www.un.org/ esa/socdev/unpfii/documents/6_session_tebtebba_iwgia.pdf (last visited [Accessed 28/07/ 2010] 
customary land tenure was impeding economic development and has not permitted any country to develop. ${ }^{43}$ It was argued that it was inconsistent with the exercise of individual autonomy and freedom in a liberal society. Some critics have further pointed out that it is an archaic base upon which to build and develop a national economy in the modern world.

There have been some countries which have replaced communal land title with individual land title frustrating the adaptive purposes for which the indigenous group developed the practice. In 1997 for example, Bangladesh under state law started registering the land titles to the indigenous individuals of central highlands an area historically comprised of communal lands. ${ }^{44}$ The indigenous individual farmers were able to secure land but because the land was limited many indigenous individuals could not get land titles exposing them to extreme poverty due to lack of land to secure their livelihoods. ${ }^{45}$ The government process to make indigenous people secure their lands led to poverty among indigenous population and decay in the way indigenous groups care need members of the society. Even though collateral effects of registering individual titles instead of communal led to an increase in land titling and security for some individual farmers, it also contributed to the collapse of the society's mechanism for caring for its poor. ${ }^{46}$

In Mozambique, customary law allows the registration of land titles in the name of the local community. This has proved to be very effective among indigenous groups and can be effective to those that require communal land registration. ${ }^{47}$ There are countries that have made provisions and succeeded in communal land registration in local communities represented by traditional authority institutions like in Ghana. There is also newly created legal bodies such as communal property in South Africa and Uganda, and a village assembly in Tanzania. ${ }^{48}$ It should be noted that the approach of communal land registration cannot hold at all times

43 Weiner, J., and Glaskin, K. (2007) Customary Land Tenure and Registration in Papua New Guinea and Australia: Anthropological Perspectives. Available from: http://epress.anu. edu.au/apem/customary/mobile_devices/ch01.html [Accessed 21/06/2010]

44 Lindsey, W. (2001) Indigenous Lands as Cultural Property: A New Approach to Indigenous Land Claims. Available from: http://www.law.duke.edu/shell/cite.pl?54+Duke+L.+J. +1061 [Accessed 21/06/2010]

45 Raja, R. (2004) Challenges for Juridical Pluralism and Customary Laws of Indigenous Peoples: The Case of the Chittagong Hill Tracts in Bangladesh. Baltimore: City College

46 Lindsey, W. (2001) Indigenous Lands as Cultural Property: A New Approach to Indigenous Land Claims. Available from: http://www.law.duke.edu/shell/cite.pl?54+Duke+L.+J. +1061 [Accessed 21/06/2010]

47 Unruh, D. (2002) Land dispute resolution in Mozambique: evidence and institutions of agroforestry technology adoption. In Meinzen-Dick, R., Knox, F., and Swallow, B (2002) Innovation in Natural Resource Management: The Role of Property Rights and Collective Action in Developing Countries. Baltimore: Johns Hopkins University Press.

48 Quan, J., and Toulmin, C. (2004) Land in Africa: Market Asset, or Secure Livelihood? Available from: http://www.iied.org/pubs/pdfs/G00166.pdf [Accessed 21/06/2010] 
in all places as indigenous groups are different and have different needs within different circumstances and places.

The government of Kenya under state law, established group ranches with borders that conflicted with traditional migration patterns of the Maasai people. The indigenous group refused to accept the state law as incompatible with their cultural norms. ${ }^{49}$ The Maasai disregarded ranch boundaries and continued their traditional semi-nomadic patterns.

\section{RECOMMENDATIONS}

The land claims by indigenous groups have developed through negotiation and judicial recognition of indigenous rights over land. The land claims litigation as an inherent right can be lengthy, costly and could lead to conflicts. In any case the courts should be the last resort if the negotiation process fails and should provide general guidance for the parties involved while leaving them to work out detailed arrangements. However, due to the nature of land claims, the more that can be resolved outside the courtroom, the greater the possibility that all issues will eventually be addressed and resolved.

It is clear that the state of the world's indigenous groups is very tenuous. The indigenous communities worldwide are in extremely delicate situations and many have already been destroyed or weakened and their security and integrity have been compromised. The conditions of indigenous groups worldwide require urgent serious social and political will within national states accompanied by resources to identify indigenous groups and assess their land claims as well as develop effective judicial structures and laws that will protect indigenous lands.

The multinational companies should work closely with both the government and the indigenous groups. They should be able to find ways of giving a plat form to indigenous groups so as to hear their views and feelings and attend to their anticipated fears which the development initiatives may bring about including disruption to their daily life styles. The government should be able to find ways of protecting the indigenous groups as the most vulnerable in society. It should avoiding sacrificing indigenous groups at the expense of economic development as it is not always that the end justifies the means. Every development initiative does not always result in an improved livelihood for the most vulnerable in society.

The adoption of the declaration on the Rights of Indigenous Peoples by the United Nations General Assembly in 2007 is significant and will

49 Coast, E. (2002) Masaai Social economic conditions: cross boarder comparisons. Available from: http://eprints.lse.ac.uk/265/1/d027_revised_version.pdf [Accessed 21/06/ 2010] 
be instrumental in shaping indigenous groups' relationships with both the international community and the states. It is for this reason that the concerned states should cooperate with the UN by affirming the rights of indigenous groups into the constitutions of the concerned state. The indigenous groups' rights over land and minerals including other sub-surface resources should be acknowledged.

\section{ConcLusion}

The concept of forcing 'development' on indigenous groups does not make them always happier or healthier, in fact very often proves disastrous. The most important question for indigenous groups' well-being is as to whether the right to their land is respected. The indigenous groups worldwide have continued to suffer the trauma of forced relocation and as they find themselves in foreign environments with nothing useful to do and where they are treated with racist disdain by their new neighbors. ${ }^{50}$ This makes them ending up being alienated without hope and many take to drugs and alcohol which very often soar.

There are reports of indigenous groups who have lost their lands and after suffering the trauma of forced relocation have resorted to committing suicide. In Canada, Indian groups who have lost their connection to their land have suicide rates up to ten times the national average and in 1995 about 56 Guarani Indians took their own lives with statistics of more than one suicide per week. ${ }^{51}$

The indigenous populations worldwide are struggling to protect their lands despite appealing to both customary and international laws as sources of land claims. The dominant groups worldwide continue to argue that indigenous groups do not have any rights to land they do not hold title under state law. It has been noted that when dominant groups help indigenous groups to secure their land, they do it to foster economic development for the entire state rather than the benefit of indigenous groups. ${ }^{52}$ In many countries, the governments have been reluctant to demarcate indigenous groups' lands because of the disruption this would cause to non-indigenous groups' interests as well as those held by the state.

The international law has been vital in settling land disputes and in protecting indigenous groups. However, there are some countries that are reluctant to bow down to the demands of international law and to change

50 Survival International (2010) Progress Can Kill. Available from: http://www.survival international.org/progresscankill [Accessed 18/06/2010]

51 Id.

52 Meinzen-Dick, R., Knox, F., and Swallow, B (2002) Innovation in Natural Resource Management: The Role of Property Rights and Collective Action in Developing Countries. Baltimore: Johns Hopkins University Press. 
customary laws that are discriminatory in character towards indigenous groups. The ILO convention number 169 despite providing guidance in protecting the indigenous groups has also come under criticism for not fully embodying the indigenous point of view. There are critical voices that points out the wording of the document as a direct affront to the rights of indigenous groups. However, despite its arguable shortcomings most indigenous leaders and organizations see it as an important step towards improving their human rights situation and are eager for governments to ratify it. 